\title{
Maintenance of the selected infant feeding methods amongst postnatal mothers at risk of HIV in the Eastern Cape Province, South Africa
}

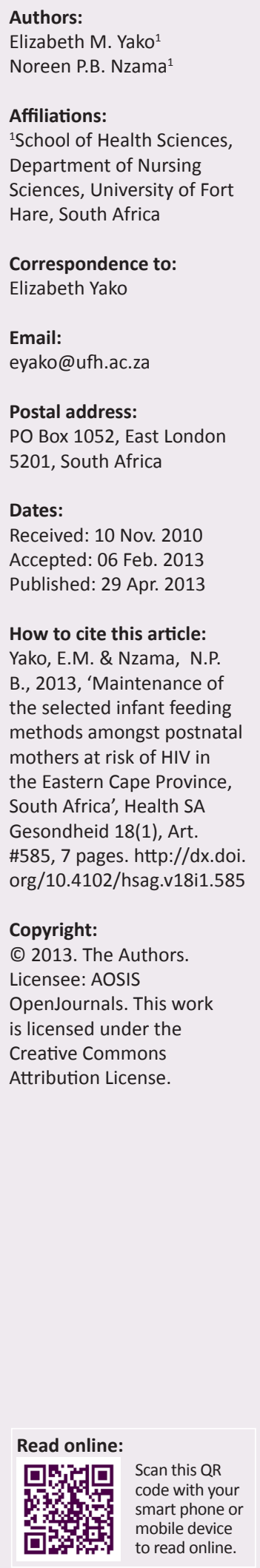

The focus of this study was to explore and describe influences on decision making related to infant feeding methods in the context of HIV and AIDS. Study objectives were: (1) to explore and describe the influences on decision making related to infant feeding methods selected by the mother during the antenatal period and (2) to describe the reasons related to a change in infant feeding method in the postnatal period. This cross-sectional study used the quantitative approach and a descriptive design. A convenience sample of 60 mothers in the prevention of mother-to-child transmission programme participated in this study. Data were collected six weeks post-delivery and analysed using SPSS 17.0 software for Windows. The mean age of the mothers was 26.5 years, range 19 to 41 years (SD 5.3). At six weeks $73 \%(n=44)$ of the mothers maintained the infant feeding method selected antenatally and $27 \%(n=16)$ had changed methods. Using a Chi-square test, the difference between groups was significant $\left(x^{2}[\mathrm{df} 1]=19, p<0.000\right)$. Every HIV-positive mother $(100 \%, n=28)$ continued with the method selected antenatally, compared with $50 \%(n=16)$ of all HIV-negative mothers $(n=32)$. The reasons for deciding to change methods included going back to school or work; illness of babies; painful breasts; and advice from significant others. Most mothers maintained the feeding methods selected antenatally. HIV-positive mothers were more likely to adhere to the initial decisions made antenatally than HIV-negative mothers.

Hierdie studie is gedoen om deeglike navorsing uit te voer en om ' $n$ beskrywende verslag te kan lewer rakende die invloed van besluitneming met die voedings metodes op babas in die konteks van MIV en VIGS. (1) Deeglike navorsing om beskrywende verslag te kan lewer rakende die besluitnemings met betrekking tot die baba voedings metodes wat deur die moeder geselekteer is gedurende die voorgeboorte periode, en (2) om die redes te beskryf aangaande die verandering in die baba voedings metode nageboortelike periode. Kwantitiewe benadering was gebruik, waartydens 60 moeders deelgeneem het, aan die oordraagbaarheid van moeder na baba. Inligting was ingewin ses weke na geboorte van die baba. Die gemiddelde ouderdom van die moeders was 26.5 jaar, gewissel tussen die ouderdomme van 19 tot 41 jaar (SD 5.3). Op ses weke het $73 \%(n=44)$ van die moeders volgehou met die voedingsmetode wat hulle geselekteer het voorgeboortelik. Sewe-en-twintig $(n=16)$ het die verkose metodes verander. Die 'Chi-square' toets was gebruik, en die verskil tussen die groepe was beduidend $\left(x^{2}[\mathrm{df} 1]=19, p<0.000\right)$. Elke MIV-positiewe moeder $(100 \%, n=28)$ het voortgegaan met die metode wat hulle voorgeboortelik verkies het, in vergeleke met $50 \%$ van moeders $(n=16)$ wat MIV negatief was $(n=32)$. Die redes vir die veranderings, was om teruggekeer na hul werk of skool, borste wat pyn en deur die invloed van ander invloedryke mense. Die meeste moeders het gebly by hul metode wat hulle voorgeboortelik gekies het, spesiaal MIV-positiewe moeders.

\section{Introduction}

Infant feeding is a natural phenomenon, which should not pose major problems to the expectant mother and her infant under normal circumstances. Yet, in the context of HIV, infant feeding poses a challenge. The expectant mother has to deal with her own health problems, the influence of relatives and neighbours, and still make a decision as to how the infant should be fed, based on counselling from health professionals. Following delivery, the mother has to implement the infant feeding method selected and maintain it in order to prevent mother-to-child transmission of HIV. Earlier studies indicate that maintaining the selected method of feeding is low amongst women in resource-constrained countries in southern Africa, including South Africa (Doherty et al. 2005:90; Shapiro et al. 2003:221; Vaahtera et al. 2001:328).

\section{Problem statement}

During the antenatal clinic visits, pregnant women are taught the importance of exclusive infant feeding for the purpose of reducing mother-to-child transmission of HIV. However, it 
is not certain that these women actually maintain the infant feeding method selected during the postnatal period, due to a variety of factors. The majority of women are unemployed in the Eastern Cape Province, as the province has a high unemployment rate of $28.3 \%$, which is higher than the national rate of 25.2\% (Statistics South Africa 2012:xvi). Even when free milk formula is available in public institutions, the choice of formula feeding and maintaining that infant feeding method become problematic due to cultural issues, community expectations, social stigma and lack of steady income to purchase additional formula (Doherty et al. 2005:93). Those who select exclusive breastfeeding also face their own problems as the concept of exclusive feeding is not within the culture of African societies (Shapiro et al. 2003:226). Besides, women in the African cultures are not the only decision makers regarding what is best for the infant, which includes infant feeding. Significant others such as the mother-in-law (Luo 2000:149) also have a major influence on what should happen to the infant, based on their own experiences. As a result of these challenges, newly-delivered mothers often find it difficult to maintain the feeding method that they had selected during the antenatal period.

\section{Significance of the study}

Infant feeding practices are thought to be associated with an increased risk of transmission of HIV to infants, more specifically breastfed infants (Luo 2000:149). The findings of the current study will add to the body of midwifery knowledge on infant feeding practices in the context of $\mathrm{HIV}$ in a low-resource setting. These findings will increase the midwives' understanding of what influences decision making related to the choice of infant feeding methods. Midwives working in the antenatal clinic will be better able to formulate strategies to assist newly-delivered mothers in maintaining exclusive breastfeeding or exclusive formula feeding in order to reduce the risk of infecting the infant with HIV.

\section{Background of the study}

South Africa has the highest prevalence of HIV in the world. Based on the 2006 statistics, the Joint United Nations Programme on HIV/AIDS (UNAIDS 2008) estimated that 5.7 million people living with HIV were in South Africa and that approximately $50 \%$ of these were women and $28 \%$ children between the ages 0-14. The National Department of Health (2010:23) estimated that the prevalence of HIV amongst 14- to 49 -year-old antenatal women in the Eastern Cape Province was as high as $28.8 \%$ in 2007 and $27.6 \%$ in 2008. Although there has been a slight decline in the prevalence of $\mathrm{HIV}$, a large number of infants still remain at risk of infection.

The United Nations guidelines state that 'when replacement feeding is acceptable, feasible, affordable, sustainable and safe, avoidance of all breastfeeding by HIV infected mothers is recommended' (WHO 2003:12). In more industrialised countries, where these criteria are met, breastfeeding by HIV-infected women has 'virtually ceased' (Coutsoudis et al. 1999:471). Consequently, infants of mothers in these countries are less likely to be infected with HIV postnatally.

\section{Purpose of the study}

The purpose of the study was to explore and describe the influences on decision making related to infant feeding methods selected by the mother during antenatal period, as well as to describe the reasons related to change in infant feeding method in the postnatal period. The findings of the study will assist the midwives working in the antenatal clinics in developing strategies to enhance exclusive infant feeding and maintain the method selected.

\section{Theoretical framework}

The study was guided by the Theory of Planned Behaviour (TPB) framework. According to this theory, intention to perform a behaviour is the central component in determining the behaviour. Intent is influenced by attitude, subjective norm and perceived control (Kerr, Weitkunat \& Moretti 2005:72). The attitude is a measure of affective feelings toward performing the behaviour. The subjective norm is the extent to which an individual thinks that significant others want her (or him) to perform the behaviour (Kerr et al. 2005:72). Perceived behavioural control includes perceived availability or non-availability of resources such as skills and knowledge (Spruijt-Metz 1999:64).

In this study, maintaining the infant feeding method selected by the mother during the antenatal period is the behaviour, and the maternal decision to either exclusively breastfeed or exclusively formula feed is the intention. In terms of the TPB framework, intention is influenced by maternal attitude toward infant feeding, as well as the subjective norm or the extent to which the mother believes significant others want her to implement the method of infant feeding selected during the antenatal period. Additionally, intention is influenced by perceived control, which is operationalised by the availability of resources such as availability of breastmilk for breastfeeding mothers and availability of formula milk, a refrigerator, access to clean water, fuel for boiling water and regular maternal income for formula feeding.

\section{Research objectives}

The objectives of this study were as follows:

- To explore and describe the influences on decision making related to infant feeding methods selected by the mother during antenatal period.

- To describe the reasons related to change in infant feeding method in the postnatal period.

\section{Research questions}

This study examined the following research questions:

- To what extent is the postnatal feeding method consistent with the infant feeding method selected by the mother during the antenatal period?

- What are the reasons for not maintaining the infant feeding method selected during the postnatal period? 


\section{Research methods Research design}

This study used the quantitative approach and the design of the study was descriptive. The descriptive design was deemed appropriate for this study, since the researchers were interested in obtaining more information about maintaining the infant feeding methods selected by the mothers antenatally in a natural setting without manipulation of any variables (Burns \& Grove 2005:232).

\section{Population}

The population in this study comprised all the mothers in the Prevention of Mother-to-Child Transmission (PMTCT) programme in the Buffalo City Municipality who were attending the postnatal clinic during the study period, irrespective of their HIV status. The total population of the Buffalo City Municipality (BCM) Local Service Area (LSA) is 272 555. This study was carried out at the Community Health Centre, which serves two main hospitals and the surrounding clinics in the area. Approximately 200 mothers receive postnatal care monthly at the Community Health Centre's PMTCT clinic (Cecilia Makiwane Hospital PMTCT Programme 2008).

\section{Sample}

A convenience sampling of 60 mothers in the Community Health Centre's PMTCT programme were enrolled in the study. The study was carried out over a period of six weeks. Every mother who visited the postnatal clinic, met the selection criteria and was willing to participate was included in the study. The postnatal clinic runs from Monday to Thursday for four hours each day. Approximately 10 participants were interviewed per week, making a total sample of 60 participants.

\section{Inclusion criteria}

Every mother who attended the PMTCT clinic six weeks postnatally, irrespective of her HIV status, was eligible to be enrolled in the study if she (1) had a singleton birth with a live, full-term baby, and (2) was able to communicate in either English or IsiXhosa.

\section{Exclusion criteria}

Mothers who were hospitalised due to postpartum complications or complications related to HIV, mental illness or other diseases were not included in the study.

\section{Measurements}

Data were collected using two instruments developed by the principal investigator. These were, (1) Maternal and Infant Profile: a questionnaire, whose items include demographic data, antenatal and delivery information and information on the baby, and (2) Infant Feeding Interview Guide: a measure with closed- and open-ended questions. The items on the Interview Guide included maternal HIV status; socio-economic factors (such as availability of clean water, refrigerator, formula feed and statement of regular maternal income); presence of other family members in the home; method of infant feeding communicated to the clinic staff; maintenance of the method; and additional substances given to the infant.

\section{Validity and reliability of the instruments}

Two experts in midwifery who are trained in Basic Antenatal Care (BANC) assessed the content of the instrument. Because of the high prevalence of HIV in South Africa, midwives have to undergo BANC training, which includes care of expectant mothers and their babies in order to prevent mother-tochild transmission of HIV (National Department of Health 2012:12). Both experts were satisfied with the contents of the instruments.

The researchers determined representative reliability by conducting a pilot study using a group of five mothers. Similar responses were found in both instances (Rossouw 2003:122).

The instruments were written in English by the principal investigator and translated into IsiXhosa by a midwife proficient in both languages. The instruments were then given to two people fluent in both English and IsiXhosa to translate back into English. They then assessed the instruments to determine that the meaning remained unchanged. This process was continued until there was $100 \%$ agreement on the meaning of the translations.

\section{Pilot test}

The instruments were pilot tested amongst five mothers attending the postnatal clinic at the Community Health Centre prior to conducting the main study. These mothers were not included in the main study. No problems were encountered with the instruments and therefore no changes were made.

\section{Data collection}

The principal investigator trained a research assistant in data collection, then explained the study and demonstrated how the instrument should be used.

The principal investigator also explained the study to the mothers whilst they were waiting for services in the postnatal clinic six weeks post-delivery. Those mothers willing to participate in the study signed a written consent form. The principal investigator and the research assistant conducted interviews in single cubicles for privacy, using the interview guides. The investigators filled in the responses on the interview guide. The interviews catered for illiterate participants and thereby minimised the problems of poor response rate and incomplete information. 


\section{Study setting}

The study was conducted in the Community Health Centre, a public health facility in the Mdantsane Township in the Buffalo City Municipality, Eastern Cape Province. A township or Location refers to a peri-urban residential area reserved for people classified as non-White from the 19th century up to the end of the apartheid era in 1994 (TheFreeDictionary n.d.). The non-White groups included Africans, Coloureds (descendants of mixed races) and Indians. The townships are found on the periphery of the cities and they are characterised by unemployment, poverty and a high crime rate. The townships sometimes also include informal settlements (TheFreeDictionary n.d.), which is the case in Mdantsane.

Mdantsane township is in the periphery of the city of East London. It is the second largest township in South Africa after Soweto, near Johannesburg (TheFreeDictionary n.d.). The residents of this township are Africans, as each racial group had its own designated area during the apartheid era. The main language is IsiXhosa (TheFreeDictionary n.d.). Data were collected from the Community Health Centre, firstly because this health facility serves two major hospitals and the surrounding clinics in the area, thus creating an opportunity of getting participants more representative of people in Mdantsane and, secondly, due to limited financial resources.

\section{Data analysis}

Quantitative data were analysed using the Statistical Program of Social Sciences (SPSS) 17.0 software for Windows (SPSS Inc. 2008). The significance level of tests was set at 0.05 . Firstly, the interview guides were checked for completeness. No missing responses were identified. Secondly, prior to data analysis, data cleaning was done. Data were checked visually for errors by conducting frequencies for categorical items and checking the means for the continuous variables (Pallant 2001:40-41). Errors were corrected and the data analysis was conducted.

The percentages and measures of central tendency were determined, for example, the mean age of the mothers and the median salary. The extent of maintenance of the chosen feeding method was determined for the entire sample and also between the groups of mothers who maintained the method of infant feeding selected in the antenatal period and those who did not. The results were expressed in terms of percentages. Data generated from open-ended questions were summarised into categories. Each of the categories was assigned a number. For example, with the question on somebody having a say in the method of infant feeding, 'mother' was assigned number 1 , 'other relative' 2 , 'spouse' 3 and 'self only' 4 These data were then coded and analysed using SPSS 17.0 software for Windows (Pallant 2001:8).

\section{Results}

The findings of the data analysis are presented as follows:

- the demographics of the participants

- method of delivery and information on the baby

- information on maternal HIV status

- choice of infant feeding method, maintaining the method selected and problems with feeding.

\section{Demography of the mothers}

Almost all of the mothers $(98.3 \%, n=59)$ were from the Mdantsane township. Only one mother was from a village close to Mdantsane township and had delivered her baby in one of the hospitals in the area. The mean age of these mothers was 26.5 years, ranging from 19 to 41 years (Standard deviation [SD]: 5.3). The mean for years of education was 12, whilst the range was from one year to tertiary. The majority of the mothers $(75 \%, n=45)$ were single; $23.3 \%, n=4$, were married; and only one mother was divorced.

Twenty-five per cent of the participants lived with their own mothers, $16.7 \%$ lived with both parents and 18\% lived with their husbands. Approximately 17\% lived with other relatives and $3.3 \%$ lived with either the father or friends.

The parents of the mothers were the main source of financial support (36.7\%). This was followed by the boyfriend at $28.3 \%$ and the husband at $18 \%$. The majority $(46.3 \%)$ reported that the family income met their needs fairly well.

Every mother $(100 \%, n=60)$ in this study had access to clean running water from the tap. Ninety-five per cent of the mothers $(n=57)$ had refrigerators, whilst the rest did not.

The majority $(61.7 \%, n=37)$ of the mothers were unemployed; only $13.3 \%$ were formally employed full-time; $3.3 \%$ were either employed on a part-time basis or informally; whilst $18.3 \%$ were students. Conversely, the majority $(85 \%, n=12)$ of the spouses of married participants $(n=14)$ were employed either full-time or part-time.

\section{The method of delivery and infant information}

Almost all the mothers $(98 \%, n=59)$ delivered in public health facilities, which is understandable since most of them were unemployed and services are provided free of charge in public health facilities. The majority $(78.3 \%, n=47)$ of the mothers had a normal vaginal delivery and almost all the participants $(93.3 \%, n=56)$ had no delivery or post-delivery complications. Every baby was born at term, as one of the inclusion criteria was full-term birth. Their apgar scores ranged between 7 and 9 after one minute post birth with a mean score of $8.8(\mathrm{SD}=0.37)$. The birth weight ranged from 2 $\mathrm{kg}$ to $4.6 \mathrm{~kg}$ with a mean of $3.1(\mathrm{SD}=0.5)$.

\section{HIV status of the mothers}

Fifty-three per cent of the mothers $(n=32)$ were HIV negative and $46.7 \%(n=28)$ were HIV positive. Of the $28 \mathrm{HIV}$-positive 
mothers, $75 \%$ were on antiretroviral (ARV) drugs. The mothers' mean CD4 count was 349.1 (SD = 178.4) and the range 73 to 765 . Every HIV-positive mother reported that she had reported her HIV status to significant others such as family members, spouse and/or a friend. The significant others accepted their HIV-positive status and gave them adequate social support.

\section{The mothers' infant feeding practices}

During the antenatal period, $45 \%(n=27)$ of the mothers chose exclusive breastfeeding and $55 \%(n=33)$ chose exclusive formula feeding. At six weeks, the pattern of infant feeding had changed. Although some still gave exclusive breastfeeding and exclusive formula feeding, some mothers also gave their infants water. Of the exclusive breastfeeding group, $21.1 \%(n=4)$ also gave the infants water, as did $26.8 \%$ $(n=11)$ of the exclusive formula feeding group. The details are presented in Tables 1 and 2 respectively.

\section{Maintenance of infant feeding method}

At six weeks, $73 \%(n=44)$ of the mothers had maintained the infant feeding methods selected during the antenatal period and $27 \%(n=16)$ did not maintain the methods selected earlier. When comparing the group of HIV-positive and HIV-negative mothers, it was found that every HIV-positive mother $(100 \%, n=28)$ had maintained the infant feeding method selected during the antenatal period. Only 50\% $(n=16)$ of all the HIV-negative mothers $(n=32)$ maintained the infant feeding method selected before delivery and the remaining $50 \%$ of this group did not. The Chi-square test was conducted to determine the proportion of those who maintained the method compared to those who did not. A significant proportion of the mothers maintained the method selected earlier $\left(x^{2}[\mathrm{df} 1]=19, p<0.000\right)$. These are presented in Table 3.

The mothers gave various reasons for changing the infant feeding method selected earlier. The majority of mothers $(50 \%, n=8)$ changed their method of infant feeding because they were students going back to school, 25\% $(n=4)$ were going back to work, whilst the rest, collectively 25\% $(n=4)$, gave other reasons, including constipation of the infant due to breastmilk, painful breasts and advice from significant others.

The two groups of mothers were also compared according to other demographic variables. The only significant difference found was with age. The independent sample $t$-test was conducted to compare the ages of the mothers who maintained the infant feeding method selected in the antenatal period and those who did not. There was a significant difference between the scores for the mothers who maintained the infant feeding method (mean $=27.4, \mathrm{SD}=4.9)$ and those who did not $($ mean $=24, \mathrm{SD}=5.9 ; t$ [df 58] $=2.28$, $p=0.028$ ) (Pallant 2001:209).

Almost all of the mothers $(98.3 \%, n=59)$ indicated that their methods of infant feeding were accepted by their relatives. One hundred per cent $(n=60)$ indicated that the infant feeding method selected was accepted by their spouses.

\section{Ethical considerations}

Prior to conducting the study, the principal investigator sought approval from the University of Fort Hare Research Ethics Committee and Eastern Cape Department of Health Research Ethics Committee. Additionally, permission to undertake the study was sought from the professional nursing person in charge of the Community Health Centre. The principal investigator presented a clear explanation of the study to the mothers. The benefits and risks of the study were explained, but there were no anticipated risks in conducting this study. It was explained to the mothers that their participation in the study would neither affect their care nor the care of their infants and that they were free to refuse to participate or to terminate their participation at any point in the study. No names would appear in the instrument. The only people who would gain access to the data were the members of the research team. Those willing to participate signed written consent forms.

TABLE 1: Infant feeding method followed by the exclusive breastfeeding group at six weeks.

\begin{tabular}{lllll}
\hline Method & Frequency & Percentage & Valid Percentage & Cumulative Percentage \\
\hline Valid Breastfeeding only & 8 & 13.3 & 42.1 & 42.1 \\
Breastfeeding plus water & 4 & 6.7 & 21.1 & 36.8 \\
Breastfeeding plus formula feeding & 7 & 11.7 & $\mathbf{3 1}$ & 100.0 \\
\hline Total & $\mathbf{1 9}$ & $\mathbf{3 1 . 7}$ & 100.0 \\
\hline
\end{tabular}

Source: Data generated by study

TABLE 2: Infant feeding method by the exclusive formula feeding at six weeks.

\begin{tabular}{lllll}
\hline Method & Frequency & Percentage & Valid Percentage & Cumulative Percentage \\
\hline Valid Formula feeding only & 18 & 30.0 & 43.9 & 43.9 \\
Formula feeding plus medications & 3 & 5.0 & 7.3 & 26.8 \\
Formula feeding plus water & 11 & 18.3 & 22.0 & $\mathbf{7 8 . 0}$ \\
Formula feeding plus breast feeding & 9 & 15.0 & $\mathbf{1 0 0 . 0}$ & -100.0 \\
\hline Total & $\mathbf{4 1}$ & $\mathbf{6 8 . 3}$ & - \\
\hline
\end{tabular}

Source: Data generated by study 
TABLE 3: Mother's HIV status and infant feeding same as selected in the antenatal period cross tabulation count

\begin{tabular}{lccc}
\hline Mother's HIV Status & \multicolumn{2}{c}{$\begin{array}{c}\text { Infant feeding same as selected in the } \\
\text { AN period }\end{array}$} & Count \\
\cline { 2 - 3 } & Yes & No & \\
\hline Negative & 16 & 16 & 32 \\
Positive & 28 & 0 & 28 \\
\hline Total & 44 & 16 & 60 \\
\hline
\end{tabular}

Source: Data generated by study

\section{Discussion}

\section{Maintaining the infant feeding method}

At six weeks post-delivery, every HIV-positive mother had maintained the method selected during the antenatal period. This suggests that the health education on PMTCT may have had an impact on the mothers. They had an understanding that mixing breastfeeding with formula feeding could have detrimental effects on their infants. Conversely, only half of the HIV-negative mothers had continued with the infant feeding method selected earlier. The latter group capitalised on their HIV-negative status. The infants of HIV-negative mothers were safe as long as the mothers remained negative. In this era of the HIV pandemic, there is no guarantee that these mothers will remain negative. Therefore, adhering to one method, either exclusive breastfeeding or exclusive formula feeding, would have been safer for the baby. The National Department of Health (2007:15) stipulates that HIV-negative mothers should be counselled about postnatal transmission of HIV. The counselling could also include regular voluntary HIV testing.

The fact that the health facilities ran out of milk formula made exclusive formula feeding challenging, as more than half of the participants were unemployed and even those who were employed, as well as their spouses, earned low salaries. This study indicates the complexity of implementing the guidelines of the United Nations which state that 'when replacement feeding is acceptable, feasible, affordable, sustainable and safe, avoidance of all breastfeeding by HIV infected mothers is recommended' (National Department of Health 2007:14; WHO 2003:12). Consideration should be given to assisting poor women financially with respect to buying milk from commercial stores when the clinics run out of formula.

Some mothers showed a lack of understanding regarding exclusive breast- and exclusive formula feeding, as they gave their infants water in addition to the chosen feeding method. The national policy on infant and young child feeding states that, in exclusive feeding, the baby should only be given medication in addition to the chosen feeding method (National Department of Health 2007:14). Giving the infant additional fluids puts such an infant at risk of malnutrition.

In this study, the mothers of the participants comprised the main group of those people who influenced infant feeding. Other relatives also contributed, leaving the mother little room for personal choice. These findings support Luo (2000:149), who indicated that women in low-resource settings are not the main decision makers and that other family members have a say in what is best for the infant.

The participants depended heavily on their parents for financial support and their culture also required that they respect their parents or more senior relatives regarding infant feeding. Conflicting ideas placed stress on a mother who would have liked to follow advice from the midwives but also wanted to show respect to the elders. Findings from this study support those of earlier studies indicating difficulty in infant feeding within the African context (Doherty et al. 2005:93; Shapiro et al. 2003:226). The variables of influence of significant others and availability of resources in the Theory of Planned Behaviour framework (Kerr et al. 2005:72) were also supported.

The National Department of Health (2007:13) emphasises that women should be educated regarding breastfeeding during the antenatal period, as breastfeeding is in the best interest of the infant. This study found that, although women had good intentions of breastfeeding their infants, they faced social challenges which forced them to either abandon or compromise the method by practising mixed feeding. If the mother has to go back to work or school, there is every chance that her infant will be looked after by a significant other such as the mother-in-law, as there are no day-care facilities at school or at most work places in the Buffalo City municipality. Besides, such facilities would be unaffordable for low-income earners. Expressing breastmilk and keeping it in the refrigerator is another option. However, this is not practical as these low-income women use public transport to work or school and have to leave home early. The midwives have to discuss these challenges and counsel the women before the baby is born, so that those who are faced with such challenges are able to make informed decisions, perhaps to rather settle for exclusive formula feeding in the first place (National Department of Health 2007:14). The midwives also have to educate the relatives of pregnant women so that the mothers are not pressured into switching from the selected method. Leroy et al. (2007:2) found that one of the reasons for mothers switching to breastfeeding even when free formula milk was available was pressure from relatives, thus putting the infant at the risk of HIV infection from those mothers who are HIV-positive.

\section{Implications for practice}

Midwives should educate the mothers so that they gain a better understanding of the concept of exclusive infant feeding and of the dangers of introducing other fluids too early.

\section{Limitation of the study}

Although this study provides useful information on infant feeding practices in a low-resource setting, its findings cannot be generalised to the entire Eastern Cape Province since the sample was taken from the Buffalo City Municipality only. 


\section{Recommendations}

It is recommended that a bigger study which covers the entire Eastern Cape Province should be conducted so that the results may be generalised.

\section{Conclusion}

The findings of the study presented in this paper indicate that all HIV-positive mothers continued postnatally with the infant feeding method they had selected in the antenatal period. Conversely, only $50 \%$ of HIV-negative mothers continued to use the selected method. The latter practice was safe, provided that the mother remained HIV-negative. It was also found that mothers did not have a clear understanding of the concept of exclusive infant feeding as they gave the infant water additionally, indicating the need for further education amongst expectant mothers. The mother of the participant was the main decision maker regarding the infant feeding method. Other relatives also had a say regarding how the infant should be fed. This left very little room for the infant's mother to make a choice, indicating a need to educate the relatives of pregnant women during the antenatal period.

\section{Acknowledgements}

The investigators wish to thank Miss Z. Njokweni and $\mathrm{Mr}$ J.M. Yako for assistance with data collection and statistical data analysis respectively. The principal investigator received funding (R3000) from the University Based Nursing South Africa (UNEDSA) project funded by Atlantic Philanthropies toward the research study and this is highly appreciated.

\section{Competing interests}

The authors declare that they have no financial or personal relationship which may have inappropriately influenced them in writing this article.

\section{Author's contributions}

E.M.Y. (University of Fort Hare) was the principal investigator and N.P.B.N. (University of Fort Hare) made conceptual contributions.

\section{References}

Burns, N. \& Grove, S.K., 2005, The practice of nursing research: Conduct, critique and utilization, 5th edn., Elsevier Saunders, St Louis.

Cecilia Makiwane Hospital PMTCT Programme, 2008, 'Cecilia Makiwane Hospital PMTCT monthly statistics', unpublished report.

Coutsoudis, A., Pillay, K., Spooner, E., Kuhn, L. \& Coovadia, H.M., 1999, 'Influence of infant-feeding patterns on early transmission on HIV-1 in Durban, South Africa: A prospective cohort', The Lancet 354(9177), 471-476. http://dx.doi.org/10.1016/ S0140-6736(99)01101-0

Doherty, T., Chopra, M., Nkonki, L., Jackson, D. \& Griener, T., 2005, 'Effect of the HIV epidemic on infant feeding in South Africa: "When they see me with the tins they laugh at me"', Bulletin of the World Health Organization 84(2), 90-96. http:// dx.doi.org/10.2471/BLT.04.019448

Kerr, J., Weitkunat, R. \& Moretti, M., 2005, ABC of behavior change: A guide to successful disease prevention and health promotion, Elsevier, Edinburgh.

Leroy, V., Sakarovitch, C., Viho, I., Becquet, R., Ekouevi, D.K., Bequet, L., Rouet, F., Dabis, F. \& Timeti-Konan, M., 2007, 'Acceptability of formula-feeding to prevent HIV postnatal transmission', Global Health Sciences Digest 20, 1-3.

Luo, C., 2000, 'Strategies for prevention of mother-to-child transmission of HIV', Reproductive Health Matters 8(16), 144-155. http://dx.doi.org/10.1016/S09688080(00)90198-8

National Department of Health, 2007, Infant and young child policy, Department of Health, Pretoria.

National Department of Health, 2010, Republic of South country progress report on the declaration of commitment on HIV/AIDS 2010 report, Department of Health, Pretoria.

National Department of Health, 2012, Strategic plan for maternal, newborn, child and women's health (MNCWH) and nutrition in South Africa 2012-2016, Department of Health, Pretoria.

Pallant, J., 2001, SPSS survival manual, 2nd edn., Open University Press, Berkshire.

Rossouw, D., 2003, Intellectual tools: Skills for the human sciences, Van Schaik, Hatfield.

Shapiro, R.L., Lockman, S., Thior, I., Stocking, L., Kebaabetswe, P., Webster, C., Perter, T., Marlink, R., Essex, M. \& Heymann, J., 2003, 'Low adherence to recommended infant feeding strategies amongst HIV-infected women: Results from the pilot phase of a randomized trial to prevent mother-to-child transmission in Botswana', AIDS Education and Prevention 15(3), 221-230. http://dx.doi.org/10.1521/ alDS Education and

SPSS Inc., 2008, SPSS statistics for windows, version 17, SPSS Inc., Chicago, IL.

Spruijt-Metz, D., 1999, Adolescence, affect and health, Psychology Press, Hove.

Statistics South Africa, 2012, 'Quarterly labour force survey: Quarter 1, 2012', viewed 14 September 2012, from www.statssa.gov.za

TheFreeDictionary, n.d., 'Townships (South Africa)', viewed 14 September 2012, from http://www.TheFreeDictionary.com/township

UNAIDS, 2008, 'South Africa: Country situation', viewed 08 January 2010, from www. unaids.org

WHO, 2003, 'HIV and infant feeding: A guide for health care managers and supervisors', viewed 08 January 2010, from http://www.who.int/maternal_child_adolescent/ documents/9241591234/en/index.html

Vaahtera, M., Kulmala, T., Heitanen, A., Ndeka, M., Cullinan, T., Salin, M.L. \& Ashton, P., 2001, 'Breastfeeding and complementary feeding practices in rural Malawi', Acta Paediatrica 90(3), 328-332. http://dx.doi.org/10.1111/j.1651-2227.2001. tb00313.x 